\title{
Examining the Experiences of Preschoolers on Programming via Tablet Computers
}

\author{
Okul Öncesi Çocuklarının Tabletlerle Programlama Deneyimleri
}

\author{
Nuray GEDÍK* \\ Mustafa ÇETİं** \\ Ceren KOCA ${ }^{* * *}$
}

\begin{abstract}
The purpose of this study was twofold. Firstly, the reactions of children aged 5-6 were analyzed in their efforts to use an application aimed at teaching the basics of programming concepts (i.e., sequencing, loops, conditions) on tablet computers. Secondly, the researchers reported on the implications of the approaches during the delivery of programming education to preschool children. A four-week, design-based study was conducted with 20 preschool children. During this study, as the children used a tablet application their reactions were observed and they were also asked to share their views and experiences. There were times when the children met with difficulties and needed adult assistance. If they felt a sense of failure or inadequacy during their engagement with advanced parts of the program, they displayed signs of boredom. Those children who had difficulty asked for help from others who had succeeded. The researchers also monitored the phases which other children had reached and who perceived the implementation as a competition. The boys seemed to be more confident in the application phases. The results of the study indicate that for young children to successfully use tablets for programming, initial training in the use of tablets that incorporate concrete activities and basic programming instruction under non-distracting conditions are needed.
\end{abstract}

Keywords: Early Childhood, Coding, Mobile Applications, Tablet Computers, Computer Education

Öz: Bu çalışmanın amacı 5-6 yaş çocuklarının programlama ile ilgili deneyimlerini incelemek ve programlama eğitimi uygulanmasındaki güçlükleri belirleyerek, dikkat edilmesi gereken hususları ortaya koymaktır. Bu amaçla, tasarım tabanlı araştırma yöntemi kullanılan bu araştırmada 20 kişiden oluşan bir anasınıfinda hazırlık aşaması dâhil olmak üzere dört haftalık bir uygulama yürütülmüştür. Uygulamada, çocukların programlamanın temel kavramları olan sıralama, döngü ve şart konularını içeren bir tablet uygulaması ile zaman geçirmeleri sağlanmış ve bu program ve çevreleri ile olan etkileşimleri gözlemlenmiştir. Kaydedilen uygulama süreçleri, çocuklara uygulama sonunda sorulan sorular ve gözlem notları temel veri kaynaklarıdır. Uygulama sürecinde çocukların büyük ölçüde heyecanlı ve mutlu oldukları görülmüștür. Ancak, çocuklar başarısızlık duygusunu hissettiklerinde, zorlandıkları bölümlerde ya da benzer bir hedefin tekrarının çok olduğu bölümlerde sıkılma ifadeleri göstermişlerdir. Çocukların bir kısmı yardıma ihtiyaç duyduklarında arkadaşları ile iletişime geçmişler, yalnız çalışmaktansa iletişim halinde çalışmaya devam etmişler, yetişkinlerden yardım alamadıkları durumlarda akranları ile iletişim kurmuşlar ve yardım talebine bulunmuşlardır. Erkek çocuklar kız çocuklarına göre kendilerinden daha emin görünmüşlerdir. Çalışmanın sonuçları tabletle programlama eğitimi sürecinde, somut etkinliklerle yürütülen ön çalışmaların önemini vurgulamaktadır.

Anahtar Sözcükler: Okul Öncesi Eğitimi, Kodlama, Mobil Uygulamalar, Tablet Bilgisayarlar, Kodlama, Bilgisayar Eğitimi

\footnotetext{
* Asst. Prof. Dr., Akdeniz University, Faculty of Education, Department of Computer Education \& Instructional Technology, Antalya.ngedik@akdeniz.edu.tr

** Res. Asst., Akdeniz University, Faculty of Education, Department of Early Childhood Education, Antalya. cetinmustafacetin@gmail.com

*** Doct. Cand., Middle East Technical University, Faculty of Education, Department of Elementary and Early Childhood Education, Ankara. cerentunc1@gmail.com
} 


\section{Introduction}

Starting from an early age the integration of computing education into curricula has recently been an overarching effort in many countries (e.g., England, Finland, France, USA etc.). The advocates of these efforts mainly support the idea that the introduction of computing education at an early age can change the role of children from consumers to future producers of information technologies, which should enable countries to remain competitive (Furber 2012; Akpınar \& Altun 2014; Manches \& Plowman 2017). There is also hesitation concerning introducing computing education, especially programming, at an early age, that may not be developmentally appropriate; and the lack of teacher preparedness and evidence based approaches would hinder its potential positive effects (Bayhan, Olgun \& Yelland 2002; Manches \& Plowman 2017). Although the potential advantages of the introduction of information and communication technologies (ICT) to children at an early age have received agreement among policy makers, practitioners, academics, and parents (Plowman \& Stephan 2005), little is known about the related pedagogy and the approaches for computing education (Cooper, Bookey \& GruenBaum 2014).

Computer programming, defined as the basis of digital technologies, is regarded as an important skill for children to acquire, as it is thought to be a skill that likely will be needed in their future careers (Rushkoff 2010; The Partnership for $21^{\text {st }}$ Century Skills 2009). However, the appropriate age for the introduction of programming or computing education is still vague (Manches \& Plowman 2017). Studies show that children around the age of 4 can understand the basic computer programming concepts and produce simple robot projects (Bers et al. 2002). Sequencing, an essential skill for programming, (Kazakoff, Sullivan \& Bers 2013) is among the abilities that this age group has. Children of this age not only accumulate the alternate actions to repeat afterwards, but they also have the ability to make use of them to create different sequencing in other situations and generalize them to other contexts (Morgado, Kruz \& Kahn 2010). According to Papert (1980), rather than memorizing the facts or practicing the skills, what really matters is to support them to discover the facts and generalize them as they do in their daily activities. The study by Mattoon, Bates, Shifflet, Latham, and Ennis (2015) showed that both digital and traditional manipulatives helped improve preschoolers' computational skills.

Most studies on programming education discuss systems like Logo, which was initially designed as a floor-turtle and later as an on-screen geometrical drawing of a frog (Harvey, 1997). These studies assert that programming has a positive effect on children's development of cognitive skills. As a pedagogical activity, computer programming supports the development of cognitive skills, such as problem solving (Fessakis, Gouli \& Mavroudi 2013). In addition, programming positively affects such children's skills as reflection and creative thinking, and also higher cognitive skills and their ability to provide directions (Clements \& Gullo 1984). Several other studies stress the positive effects of programming on certain mathematical skills. According to Kazakoff and Bers (2012), in-class programming activities improved children's sequencing skills significantly. In another study of children involved in programming-based robot construction, the researchers found that programming activities significantly improved the children's sequencing performance (Kazakoff, Sullivian \& Bers 2013). In a study by Reimer (1985), Logo was found to have strengthened the children's visual motor skills, visual memory, and visual identification skills (Clements 1999). While supporting all of these developmental areas, programming also positively influences children's social skills. While working with Logo, children mostly prefer peer interactions rather than seeking adult assistance (Miller \& Emilhovic 1986), but teachers need to scaffold and encourage their students (Clements, Nastasi 
\& Swaminathan 1993). Computers also entail content that can attract children's attention and increase their motivation (Bergin, Ford \& Hess 1993; McCarrick \& Lee 2007). Since the attention span of preschoolers is much shorter compared to other age groups, as much rich content as possible is needed to attract the attention of children to the target content.

Programming education typically has been provided in a computer environment. More recently, mobile platforms with advanced features have been used as well. For example, there are applications for diverse age groups in K12 and available for tablet computers and smartphones such as Kodable, Scratch \& Scratch Jr, MS Kodu, Logo, Alice, and Betie, some of which are also available on computers. These applications aim to teach children basic concepts and skills of programming via game-like and graphic platforms. Applications with specific features (such as visualization in animations and games, concretization, narration, etc.) help children to effectively build programming skills. In particular, features such as a simplified syntax, instruction symbols, instant applicability of instructions, and the utility of adapting programming paradigms to metaphors make these applications appropriate for children's skills development (Fessakis et al. 2013). When animated characters and similar elements are employed, the abstract concept of programming becomes more concrete for children. These kinds of applications are also useful for translating complex programming language to a child's level in an entertaining way (Stolee \& Fristoe 2011).

As the employment of emerging mobile technologies in preschool education is relatively new, few studies have been conducted on tablet computers in this context (Sahin et al. 2014). Existing studies focused on the use of computers and robotics in preschool education. A need exists for studies that examine children's reactions to using tablet computers for learning programming concepts and investigate the approaches for designing programming education to preschoolers. This study was designed to analyze the programming experiences of preschool children and to identify issues that were encountered during these experiences. The process of their programming education involving tablet computers was also examined. Two research questions guided this investigation:

1. What social, emotional, and physiological reactions emerge among preschoolers while they are programming on tablet computers?

2. What are the aspects of designing and delivering programming education to preschoolers via tablet computers?

\section{Method}

To examine preschooler's experiences related to programming education, a design-based approach was adopted in the study (Collins, Joseph \& Bielaczyc 2004; Reeves 2006) in an attempt to understand the design and implementation steps of the process. Data was collected using qualitative methods to provide in-depth knowledge about the design-based implementation process.

\section{Programming Application and Content}

In this study, the researchers used a mobile application named Kodable on students' iPads. Kodable is a mobile application for children aged 5 and up and aims to offer an introduction to programming concepts via drag and drop instructions. Little round characters as the members of fuzzfamily are in the planet Smeeborg and require students' help to navigate in the mazes. This application was selected for participants due to its appeal, easy use, and basic curriculum that introduce fundamental programming concepts of sequence, conditions, loops, and functions. It is regarded as having a child-friendly interface (Garcia-Penalvo, Reers, Jormanainen \& 
Vermeersch 2016). Considering the curriculum of the participants and after negotiating with the classroom teacher, sequence, conditions, and loops were included within the scope of the study.

\section{Participants}

The participants in the study were 20 children from a private school's preschool class in a large province of Turkey. The preschoolers were around 5-6 years old, and their class contained 11 girls and 9 boys. Before conducting the study, the necessary permissions were obtained from their parents, and all of the research activities were observed by their classroom teacher. To identify the participants' prior interactions with technology, their parents' perceptions were queried. According to information from the parents, 16 students watched TV every day, while four students watched TV only a few times in any given week. A majority of parents indicated that their children used computers, mobile phones, and computer tablets from time to time and a few only stated that their children had never used these technologies before.

\section{Data Collection Tools}

Data were collected during the 2014 Spring. Before the study, unstructured interviews were held with the classroom teachers at the school, and structured observations were made in the classrooms. The aim of these interviews and observations was to determine the school and classroom environment, and to obtain detailed information about the teaching and learning processes.

During the implementation, data was mainly collected from observation notes and video recordings. The data from the video recordings was analyzed to determine both the children's reactions during the implementation periods and the processes of the implementation phases. Additionally, the children were asked to share their thoughts and experiences after each activity via video recordings.

\section{Procedure}

Before the implementation, a preliminary study was performed, intended to help the children understand the tablet application. As suggested in the curriculum document of Kodable website for teachers, a tangible platform was created in the classroom. Imitating the maze in the application, this platform included cue cards, rewards on the route, the target at the end of the route, a toy dog following the route, and an operator leading the dog. With the help of this platform, the children could make clear and easy inferences about routes and targets. The sequences, loops, and conditions were all introduced in the platform. The children observed the operator and gave directions to proceed and to reach target. The main reason for this is that preschoolers are at the concrete operational stage, and so they can accomplish these kinds of cognitive activities. However, due to the small classroom environment and large class size, the children could not interact with the platform individually.

The implementation phase in total lasted three weeks. Activities were conducted for three hours per week by the researchers and the ICT teacher at the school. During this process, the children were taken to another class in groups, and they were asked to start using the programming application on iPad tablets, beginning from the first level. During the implementation, the children were allowed to spend time using the programming application while their reactions to it and interactions within their environment were observed and recorded. The process took about 30 minutes for each student. Throughout the implementation, the children were followed; they were guided whenever they needed assistance; and observation notes were taken. Additionally, the children were asked to share their thoughts and experiences. 


\section{The Data Analysis}

All the observation notes and implementation recordings were analyzed using the content analysis method of the qualitative data analysis approach. The recordings of each process were reviewed and analyzed in relation to the research questions, and they were interpreted with reference to the observation notes. They were analyzed using the thematic analysis process of the content analysis method. For this aim, all data were grouped under themes (e.g., children's reactions) and sub-themes (e.g., social-emotional reactions). Each researcher coded the data and interpreted the results via consensus. Original quotes from the children were extracted, and the students' names were given pseudonyms for the sake of their privacy.

\section{Findings}

The results of the content analysis were grouped into two categories: the children's reactions (emotional and physiological reactions) during the implementation, and the processes in the implementation phases.

\section{Children's Reactions Observed During the Study}

\section{Social-Emotional Reactions}

During the three-week study, the researchers observed the children's emotional reactions while they were using the programming-based application. Their reactions are characterized as excitement, happiness, curiosity, joy, signs of boredom, and desperation.

Throughout the study, the children generally appeared excited and happy. During the first phases, they were impatient and willing to start the activity on the computer tablets. The teacher tried to attract their attention to describe and explain the activity; however, it was a difficult task to manage. The children frequently tried to use their computer tablets before listening to the instructions, and they had difficulty following them.

When children felt a sense of failure in certain phases, they displayed signs of boredom. They usually expressed their feelings of desperation and boredom with sentences like, "I cannot do this, you see; I cannot pass this level - ugh, it is too difficult!".

In the course of the implementation, there was one child (Burcu) who had never used a computer tablet before. Therefore, she struggled in each phase of the implementation. Since she was much more interested in the computer tablet itself, rather than the directions, she had difficulty performing certain actions properly. This situation caused her to feel inefficient and made her complain tearfully: "Teacher, I cannot do this. How will I manage this? I cannot pass this level".

The girls were more anxious about using the tablet computers than the boys. The boys seemed more confident during the application phases. While the boys had shown more desire to advance the levels, the girls were more inclined to finish a level quickly and then leave the application.

Although the effects of technological devices on social skills were beyond the scope of this study, the social interactions between some of the children during the research process were notable. Specifically, those children who had difficulty in some phases asked for help from others who had moved to the next level. However, the children usually helped others by doing the required procedures for the student in need rather than by providing advice and guiding. To illustrate:

Ali: Teacher, can I help my friend? 
Teacher: Of course, you can.

Ali: Ok, now, you will put it there. Purple one on it. Then go down there. [Doing all these tasks himself] Stick up through the pink one. Here you go!

Though rarely seen, some children did try to help their friends by making them find the mistakes by themselves. To illustrate:

Ayşe: I did it wrong again. I cannot understand what to do.

Ipek: What is wrong? What did you do? No, show it with your hand first.

Ayşe: I put that there, then this, this... Is it ok? [When it was correct, she

joyfully hugged her friend].

At the end of the activities, the children were asked to share their thoughts. Some of their responses were:

Ali: The game was fun, but if I could have dragged them [the characters] without the boxes, it would have been more fun.

Mehmet: The game is fun and not boring. In this game, the monster wants to collect all the money and take it home. He can go without collecting it, but as I want him to collect it, I take him to every single road. Zeynep: I loved the fluffy monster the most.

Arda: The game is not fun, it is boring. The stages are a bit hard.

Ayșe: The game is nice but tiring. It was better at the beginning.

As seen from the responses of the children, when they felt challenged especially in the several levels of loops and conditions, their opinions about the application were generally negative. They were very much interested in elements of the application including the characters, interface, and flow of levels.

\section{Physiological Reactions}

During the use of the application, the children mostly expressed themselves physically. Their reactions occurred throughout the process and simultaneously with their emotional reactions. The most common reactions were applauding, standing up and cheering, hugging someone, crying, hitting one's own head, and tapping on the computer tablet harshly.

As an example of a physical reaction, when the children were successful, they tended to applaud; this is a basic rejoicing reflex. Burcu, who had felt intensely unsuccessful, displayed physical reactions such as crying and hitting herself slowly. We also observed that some children were standing up during the difficult stages, and checking their friend's computer tablet frequently. Some only placed their heads between their hands or scratched their heads.

\section{Processes in Implementation Phases}

The children had problems with physical directions during the preliminary study. As they could not make an exact distinction between right and left, they struggled to understand directions (e.g., going left for 5 steps and jumping and then turning right and going up 3 steps). Additionally, the insufficient classroom size was another problem which hindered individual interaction with the platform. Therefore, it can be assumed that the effort aiming to concretize the programming concepts was unsuccessful to help children get a concrete sense of loops, and conditions subject.

During the implementation, those children who previously knew how to use tablets were 
able to understand what to do with the application without any instructions. As the classroom teacher indicated, concrete activities focusing on sequencing and pattern forming which had been conducted throughout the term now became useful. However, when knowledge of "loops" and "conditions" (which was not included in the preschool education program) was required in certain stages of the application, the children became lost and did not know what to do. They needed help or instructions. Apparently, the demonstration stage that did not allow individual participation for finding paths was inadequate for the children to concretely understand these issues. This indicates the critical role of preliminary studies and individualized instructions prior to such types of programming activities. Providing an adequate number of informative activities can decrease the problems that will face the children. In addition to the preliminary information, working with each child individually is also important as the application in the tablet environment provides only two dimensional (2D) visuals rather than 3D ones - which are more concrete and help children to understand more easily.

Another important find is the importance of an optimal number of students per teacher. The study was carried out with different numbers of children in groups, which met at the same time; this helped to identify an optimal student-teacher ratio. A group of six students and three teachers provided the most productive study environment, compared to other groups (e.g., ten children to three teachers). When the number of students per teacher increased, the teachers struggled to care for each student personally, and sometimes were unable to provide feedback or to help them when the child was in need of assistance.

\section{Discussion}

During the problem solving and strategic planning development processes, the children maintained their learning interests. Simultaneously, they displayed social interactions including competence and cooperation, which contribute to their learning process as is suggested by Fessakis et al. (2013). According to Sehridan and Williams (2006), preschoolers tend to compete and race in physical activities and in computer games. In the current study, there were children who tried to follow which phase in the computer game the other children had reached. Parallel to the literature, this shows that these children perceived the use of game-based applications as a being a form of competition.

For several children, it was their first encounter with technological devices such as computer tablets in an educational institution. These kinds of technological devices are not used frequently in preschool education, and so the children's interest and sense of wonder may be aroused. This can yield both positive and negative consequences for the effectiveness of their first-time usage.

Similar to the study of Fessakis et al. (2013), we observed that in addition to competition, children engaged in social interactions with each other, including peer-to-peer communication and cooperation. The children asked for help from their peers and supported each other, as Freeman and Smrindayke (2001) suggested. In addition to reinforcing cooperation skills, these social interactions affect children's memory skills. Children engage in social interactions with their friends while working on computers, and their concentration is directed to both the computers and to each other (King \& Alloway 1992). Similarly, the results of this study also indicate that when they needed assistance, the children engaged initially in peer-to-peer communication, and then seek adult assistance.

According to the experimental study of Perlmutter, Behrend, Kuo, and Muller (1989), the free recall and cued recall skills of children working with their peers in a group were rated at a 
higher level than those of students who studied alone on computers. Similarly, the help of peers made all children complete stages in this study.

In a study carried out by Bergin, Ford, and Hess (1993), 95 preschoolers were video recorded while they were playing computer games. They reported positive physical reactions, such as excited behaviors, singing, pointing to the screen, and laughing. In another study performed with 12 preschoolers using computers, the children's gestures and verbal statements were recorded (Liu 1996). Their results demonstrated that $75 \%$ of the children continually laughed and smiled during their interactions with computers. Likewise, in the present study, similar positive physical reactions were found (applauding, standing up and cheering, and hugging someone). But unlike the other studies, the results of this study also showed that the children displayed negative physical reactions, such as crying, hitting one's own head, and tapping on the tablet harshly. These negative reactions may be a result of the feeling of failure that the children experienced in some phases of the tablet application (e.g., when working on loops and conditions). The main reason can be the use of a result-oriented application rather than a process-driven one in this study.

The results supported previous literature with Logo in that the teacher must encourage and support the children, and also manage the teaching (Clements et al. 1993; Fessakis et al. 2013). Moreover, the appropriate provision of environmental stimuli by someone who knows the children's needs, interests, and skills enables the students to relate their experiences to daily life, so that they will be more willing to search for new information (Klein, Nir-Gal \& Darom 2000). Providing diverse activities to support problem solving skills can also be suggested to promote programming skills (Kalelioğlu \& Gülbahar 2014). Finally, finding an optimum children-toteacher ratio is highly important for the success of an implementation, as was observed in the current study.

\section{Conclusion and Recommendations}

This study showed preliminary studies that concretize the basic concepts of programming have a vital importance for preschoolers as they significantly enhance the effectiveness of their learning processes. Depicting the programming concept for the tablet's use in a concrete way for preschoolers was an aspect that was not fully realized, indicating the basic limitation of the study. It is believed that due to the wide space given to patterning and sequencing concepts in the curriculum of students, they were comfortable in passing easily through the phases that require sequencing skills. However, they generally experienced difficulty in the phases that include loops and conditions, with these phases not given much space in the curriculum of traditional classroom hours. The result was that they became bored from time to time. This situation may have been caused by the limited time span of the study (not enough time to train the children adequately) and/or insufficient concrete activities. The suitability of these topics within the mental horizon of preschoolers also needs to be examined. Obviously, children struggled to learn within the 2D environment provided by the application. Hence, in light of the results of this study, we recommend that more time should be allocated for future research studies on this topic and that more concrete instructional activities should be incorporated.

Due to the insufficient time period allocated for this study, only one preliminary study for the concretization of the concepts had been conducted and this clearly was insufficient to attract the children's attention. Preliminary studies which include a route and target are very important in constituting concrete learning activities. Thus, the number of preliminary studies should be increased, and the use of concrete activities should be emphasized to introduce children more 
tangibly to the basic steps of programming skills. In order to enable each child to experience the procedure first-hand, spacious places such as a garden, playroom, or sports hall should be used, and the activities should be performed with a high teacher to student ratio in smaller groups, if possible. At the very beginning of the implementation process, after directions for their use have been fully explained, tablets can be given to the children, to prevent the children from focusing on the tablets rather than following the instructions. Lastly, the instructions should be provided to the children as a group; but if this is not possible, they can be taught to the children individually.

This study contains some limitations. Firstly, the duration of the study was insufficient to explain whether or not their interest was derived (and to what degree) from the novelty effect, that can be caused by the presence of computer tablets for the first time in the classroom. The novelty effect may be more limited in longer-term studies. Secondly, during the procedure, the children were taken to a different classroom from their own, in small groups. Consequently, the study was limited by the small classroom setting and the group sizes. The classroom teacher could not be included during the implementation process, which was also a limitation. Finally, the design features of the tablet application (graphical design, content design, etc.) imposed another limitation on the study.

\section{Note}

The first draft of this study was presented in 2014 International Conference on Instructional Technologies Symposium (ICITS). 


\section{REFERENCES}

Akpınar Y. \& Altun A. (2014). "Bilgi Toplumu Okullarında Programlama Eğitimi Gereksinimi”. Illkögretim Online 13/1 (2014) 1-4.

Bayhan P., Olgun P. \& Yelland N. J. (2002). "A Study of Pre-School Teachers' Thoughts About Computer Assisted İnstruction”. Contemporary Issues in Early Childhood 3/2 (2002) 298-303. doi.org/10.2304/ciec.2002.3.2.11

Bergin D. A., Ford M. E. \& Hess R. D. (1993). "Patterns of Motivation and Social Behavior Associated with Microcomputer Use of Young Children”. Journal of Educational Psychology 85 /3 (1993) 437-445.

Bers M. U., Ponte I., Juelich C., Viera A. \& Schenker J. (2002). “Teachers as Designers: Integrating Robotics in Early Childhood Education”. Information Technology in Childhood Education Annual 20021 (2002) 123-145.

Clements D. H. \& Gullo D. F. (1984). "Effects of Computer Programming on Young Children's Cognition”. Journal of Educational Psychology 76/6 (1984) 1051-1058.

Clements D. H. (1999). "The Future of Educational Computing Research: The Case of Computer Programming”. Information Technology in Childhood Education Annual 19991 (1999) 147-179.

Clements D. H., Nastasi B. K. \& Swaminathan S. (1993). "Young Children and Computers: Crossroads and Directions From Research”. Young Children 48/2 (1993) 56-64.

Collins A., Joseph D. \& Bielaczyc K. (2004). "Design Research: Theoretical and Methodological Issues”. Journal of the Learning Sciences 13/1 (2004) 15-42.

Cooper S., Bookey L. \& Gruenbaum P. (2014). "Future Directions in Computing Education Summit Part One: Important Computing Education Research Questions, Technical Report CS-TR-14-0108-SC, Stanford University”. Retrieved January 15, 2017 from http://ilpubs.stanford.edu:8090/1117/

Fessakis G., Gouli E. \& Mavroudi E. (2013). "Problem Solving by 5-6 Years Old Kindergarten Children in a Computer Programming Environment: A Case Study”. Computers \& Education 63 (2013) 87-97.

Freeman N. K. \& Somerindyke J. (2001). "Social Play at the Computer: Preschoolers Scaffold and Support Peers' Computer Competence”. Information Technology in Childhood Education Annual 1 (2001) 203-213.

Furber S. (2012). Shut Down Or Restart: The Way Forward for Computing in UK Schools. London 2012.

García-Peñalvo F. J., Rees A. M., Hughes J., Jormanainen I., Toivonen T. \& Vermeersch J. (2016). “A Survey of Resources for Introducing Coding into Schools”. Ed. F. J. García-Peñalvo, Proceedings of the Fourth International Conference on Technological Ecosystems for Enhancing Multiculturality (TEEM'16) 2-4 (2016) 19-26. New York.

Harvey B. (1997). Computer Science Logo Style: Symbolic Computing. London 1997.

Kalelioğlu F. \& Gülbahar Y. (2014). "The Effects of Teaching Programming Via Scratch on Problem Solving Skills: A Discussion From Learners’ Perspective”. Informatics in Education 13/1 (2014) 33-50.

Kazakoff E. R. \& Bers M. (2012). "Programming in a Robotics Context in the Kindergarten Classroom: The Impact on Sequencing Skills". Journal of Educational Multimedia and Hypermedia 21/4 (2012) 371-391.

Kazakoff E. R., Sullivan A. \& Bers M. U. (2013). "The Effect of a Classroom-Based Intensive Robotics and Programming Workshop on Sequencing Ability in Early Childhood”. Early Childhood Education Journal 41/4 (2013) 245-255.

King J. \& Alloway N. (1992). "Preschooler's use of Microcomputers and Input Devices”. Journal of Educational Computing Research 8/4 (1992) 451-468.

Klein P. S., Nir-Gal O. \& Darom E. (2000). "The use of Computers in Kindergarten, with or Without Adult Mediation; Effects on Children's Cognitive Performance and Behavior”. Computers in Human Behavior 16/6 (2000) 591-608.

Liu M. (1996). “An Exploratory Study of How Pre-Kindergarten Children Use ihe Interactive Multimedia Technology: Implications for Multimedia Software Design”. Austin, Texas: University of Texas at Austin. Retrieved from http://files.eric.ed.gov/fulltext/ED396713.pdf

Manches A. \& Plowman L. (2015). “Computing Education in Children’s Early Years: A Call for Debate”. 
British Journal of Educational Technology 48/1 191-201. Doi:10.1111/bjet.12355

Mattoon C., Bates A., Shifflet R., Latham N. \& Ennis S. (2015). "Examining Computational Skills in Prekindergarteners: The Effects of Traditional and Digital Manipulatives in a Prekindergarten Classroom”. Early Childhood Research \& Practice 17 /1 (2015).

McCarrick K. \& Li X. (2007). "Buried Treasure: The Impact of Computer Use on Young Children's Social, Cognitive, Language Development and Motivation”. AACE Journal 15/1 (2007) 73-95.

Miller G. E. \& Emilhovic C. (1986). "The Effects of Mediated Program Instruction on Preschool Children's Self-Monitoring”. Journal of Educational Computing Research 2 /3 (1986) 283-297.

Morgado L., Cruz M. \& Kahn K. (2010). "Preschool Cookbook of Computer Programming Topics”. Australasian Journal of Educational Technology 26/3 (2010) 309-326.

Papert S. (1980). Mindstorms: Children, Computers, and Powerful Ideas. New York 1980.

Perlmutter M., Behrend S. D., Kuo F. \& Muller A. (1989). "Social Influences on Children's Problem Solving”. Developmental Psychology 25/5 (1989) 744-754.

Plowman L. \& Stephen C. (2005). “Children, Play, and Computers in Pre-School Education”. British Journal of Educational Technology 36/2 (2005) 145-157.

Reeves T. C. (2006). "Design Research from a Technology Perspective”. Eds. J. Van den Akker, K. Gravemeijer, S. McKenney \& N. Nieveen, Educational Design Research (2006) 52-66. London.

Rushkoff D. (2010). Program or to be Programmed: Ten Comments for a Digital Age. New York 2010.

Sahin M. C., Tas I., Ogul I. G., Cilingir E. \& Keles O. (2014). "Literature Review on the Use of Tablet Computers in Preschool Education”. European Journal of Research on Social Studies 1/1 (2014) 80-83.

Sheridan S. \& Williams P. (2006). "Constructive Competition in Preschool”. Journal of Early Childhood Research 4/3 (2006) 291-310.

Stolee K. T. \& Fristoe T. (2011). “Expressing Computer Science Concepts Through Kodu Game Lab”. Proceedings of the 42nd ACM Technical Symposium on Computer Science Education (2011) 99-104. Dallas, Texas. Retrieved from http://dl.acm.org/citation.cfm?id=1953197

The Partnership for 21st Century Skills (2009). P21 Framework Definitions. Retrieved September 13, 2014, from http://www.21stcenturyskills.org. 